\title{
Impact of Income Tax Performance on the Application of Accounting Billing Systems in Jordan: Applied to Income Tax Directorates in Jordan
}

\author{
Ayman Saleh Mustafa Harb \\ ${ }^{1}$ Zarqa University, Jordan \\ Correspondence: Ayman Saleh Mustafa Harb, Zarqa University, Jordan.
}

Received: July 6, 2020

Accepted: September 9, 2020

Online Published: September 21, 2020

doi:10.5430/ijfr.v11n5p172

URL: https://doi.org/10.5430/ijfr.v11n5p172

The Research is funded by the Deanship of Research in Zarqa University, Jordan.

\begin{abstract}
This study aims to identify the impact of tax performance on the application of the accounting billing systems in Jordan, through identifying the impact of income tax on the application of the accounting billing systems as well as determining the impact of income tax on tax revenues.

The findings of this study indicate that there is an impact of income tax on the application of the accounting billing systems in Jordan, where the value of the correlation between the two variables reached $(0.653)$. Findings also indicate that there is an impact of income tax on the tax revenues in Jordan, reaching a correlation value of $(0.650)$ between the two variables. The researcher recommended that the tax billing system be applied to all sectors to combat tax evasion and to apply the principle of tax justice.
\end{abstract}

Keywords: accounting disclosure, new investors, competitive environment

\section{Introduction}

Every country tries to fight tax evasion by establishing tax awareness among the society, fight corruption and tax evasion by adopting legal methods and systems that protect tax performance through increased revenues to the Treasury. The year 2019 has witnessed the application of the accounting billing system in an attempt to reduce tax evasion and increase state revenues. Income tax is considered a core pillar to the continuity of service provision to citizens since the country expends its tax revenues on education, health and roads.

Applying the accounting billing increases the credibility of the financial statements submitted to the Department of Income Tax, and lets the values and numbers of financial statements submitted to the Department be equilibrate, thus creating a true impression between the tax statements provider and the tax calculator, far from suspicion and tax evasion attempts.

Abu Nassar (2019) defines tax as a sum of money the taxpayer pays to the state in accordance with laws and regulations. Bensaghir (2019) defines electronic bill as a prop for paper bills containing financial and accounting information.

\section{Literature}

Bensaghir (2019) has indicated in his article the adoption of the Morrocan plan for electronic billing system of the financial and accounting regulations, to boost tax collection thus increasing state revenues. On the other hand, Al-Qarala (2018) has focused on anti-corruption resulting from tax evasion, through adopting legal methods to develop accounting billing systems, fight corruption and increase tax revenues. Leunig \& Broadberry (2013) have dealt with the impact of government policies on industry in Britain since the year (1945) resulting in the collapse of such an industry, quality deterioration and a decrease in net income and provided productive services. Mameche (2018) has referred to the International Accounting Standards of income tax affecting the financial statements, accounting discrepancies of accounting profit and tax profit, and its impact on the fairness of the financial statements. JESC (2014) has focused on the tax evasion phenomenon and how to combat that through revising tax laws. Rahhal (2011) tackled tax laws which aim at investment through incentives and attracting other investments. The study has found that tax laws are not intended to increase investment in Jordan. Yousfi (2016) has stressed the importance of 
the tax income performance investment decisions of investment- encouraging laws and agreements on investment development.Nicu and Popa (2015) has Taxes play an important role in the economy, but taxes prevent them from taking advantage of the economy's effectiveness and exploiting financial and accounting performance in moving the economy. According to Al-Qarala (2018), the purpose of taxes is to increase the state's revenues. Adherence to accounting accuracy is in terms of adherence to accounting standards.

\section{Research Method}

\subsection{Significance of the Study}

The importance of this study lies in its aim to determine the impact of income tax performance on the application of accounting billing systems in Jordan. It applies to the Jordanian Income Tax Directorates.

\subsection{Objectives of the Study}

This study aims to:

1- Determining the impact of income tax on the application of accounting billing systems in Jordan.

2- Determining the impact of income tax on tax revenues in Jordan.

\subsection{The Problem of the Study}

The problem of the study is in reducing tax evasion through the application of the accounting billing system in Jordan, thus increasing tax revenues resulting from the accuracy of the financial information provided by the taxpayer.

\subsection{Elements of the Study Problem}

1- What is the impact of income tax on the application of accounting billing systems in Jordan?

2- What is the impact of the income tax on Jordan's tax revenues?

\subsection{Study Hypotheses}

$\mathbf{H}_{01}$ : There is no statistically significant impact of income tax on the application of accounting billing systems in Jordan.

$\mathbf{H}_{\mathbf{0 2}}$ : There is no statistically significant impact of the income tax on tax revenues in Jordan.

The study comprises three variables as

- Income Tax.

- Accounting Billing Systems.

- Tax Revenues.

\section{Dependent variable}

\section{Independent variables}

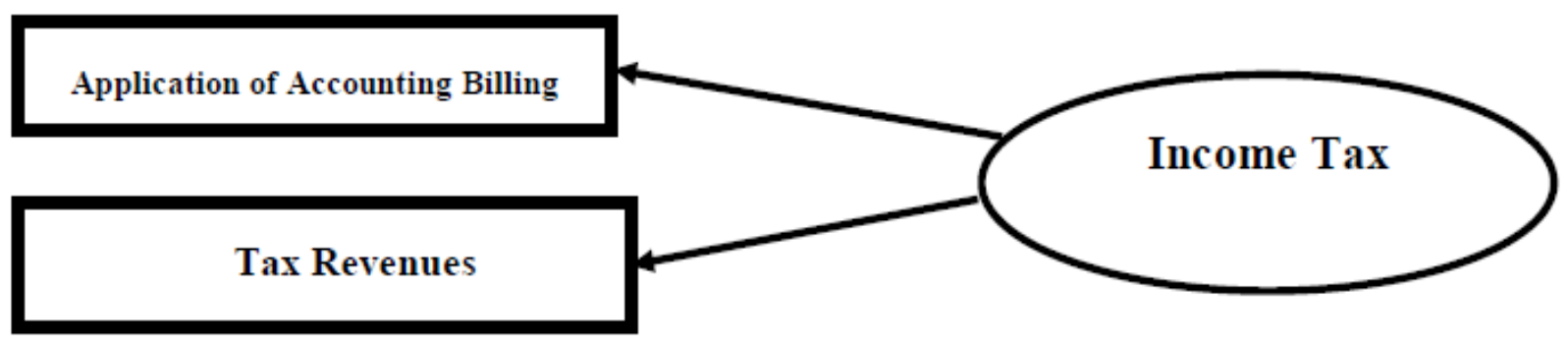

\section{Methodology and Procedures}

\subsection{Study Population and Sample}

The study population comprises all income and sales tax directorates and centres in Jordan on (31/12/2019). It included (16) income and sales tax directorates and centres. The unit of analysis are (250) individuals working in the income and sales tax directorates $(\mathrm{N}=250)$. The study population included (16) income and sales tax directorates and centres as listed below: 


\begin{tabular}{ll}
\hline $\begin{array}{l}\text { 1. Western Amman Directorate of Income and Sales } \\
\text { Tax }\end{array}$ & 9. Al-Balqa Service Centre for Income and Sales Tax \\
\hline 2. Eastern Amman Directorate of Income and Sales Tax & 10. Al-Mafraq Centre for Income and Sales Tax \\
\hline 3. Central Amman Income and Sales Tax Directorate & 11. Al-Karak Service Centre for Income and Sales Tax \\
\hline 4. Northern Amman Income and Sales Tax Directorate & 12. Al-Tafila Service Centre for Income and Sales Tax \\
\hline $\begin{array}{l}\text { 5. Southern Amman Directorate of Income and Sales } \\
\text { Tax }\end{array}$ & 14. Directorate of Service Activity \\
\hline 6. Ma'an Service Centre for Income and Sales Tax & 15. Al-Zarqa` Income and Sales Tax Directorate \\
\hline 7. Ma`daba Income and Sales Tax Service Centre & 16. Irbid Income and Sales Tax Directorate \\
\hline 8. Ajlon Income and Sales Tax Service Centre & 14. Directorate of Service Activity \\
\hline
\end{tabular}

Questionnaires will be distributed to the personnel of the Income and Sales Tax Service Directorates and Centres, who fall into the following categories:

\begin{tabular}{ll}
\hline 1. Director of the Income and Sales Tax Directorate & 6. Chief of the Tax Division \\
\hline 2. Chief of the tax collection section & 7. Chiefs of tax receivables and returns \\
\hline 3. Tax chief financial officers & 8. Tax evaluators \\
\hline 4. Tax accountants & 9. Directors or Chiefs of the Internal Audit Service \\
\hline 5. Supervisor of tax return & 10. Information technology systems \\
\hline
\end{tabular}

\subsection{Limitations of the Study}

The limitations of the study are:

1- The study community is confined to the Income and Sales Tax Services Directorates and Centres.

2- Application of the accounting billing in Jordan during (2019).

3- Lack of references and previous studies in accounting billing.

\subsection{Methods of Data Collection}

Data have been collected from secondary and primary sources based upon the impact of income tax performance on the application of the accounting billing as follows:

A) Secondary sources of references and previous studies.

B) Primary sources: A questionnaire distributed to the personnel in the Income and Sales Tax Directorates and Service Centres. It addresses the research aims and is designed based upon the secondary data. Thus, (250) questionnaires will be distributed to the personnel at the Income and Sales Tax Directorates and Service Centres.

Number of questionnaires distributed $=174$

Number of unresponded questionnaires $=32$

Number of complete questionnaires $=142$

The response percentage equals $\quad(\underline{142 \div 174=81.6 \%})$.

\subsection{Statistical Methods}

In order to analyse the data of this study, the researcher has adopted the following methods:

A) Descriptive statistics; using arithmetic mean and calculate deviation, using Alpha Cronbach formula for external consistency.

B) Using (SPSS) for data analysis.

\subsection{Hypothesis Testing of the Study}

This section analyses the independent and dependent variables, and the hypothesis testing as follows: 
Table 1 shows a consistent income tax performance in the application of accounting billing systems in Jordan (Alpha Cronbach):

Table 1

\begin{tabular}{clcc}
\hline NO. & Areas & NO of paragraphs & Alpha Cronbach value \\
\hline 1 & Income tax (Independent variable) & 10 & 0.894 \\
\hline 2 & $\begin{array}{l}\text { Application of accounting billing systems } \\
\text { (Dependent variable) }\end{array}$ & 10 & 0.870 \\
\hline 3 & Tax revenue (Dependent variable) & 10 & 0.844 \\
\hline & Total & $\mathbf{3 0}$ & $\mathbf{0 . 9 3 7}$ \\
\hline
\end{tabular}

Table 1 shows that the areas of the income tax performance in the application of the accounting billing systems in Jordan enjoy high-degree values of internal consistency, reaching a total of (0.937) for the study areas. The persistence value for the income tax reached (0.894), (0.870) for the application of accounting billing systems / first dependent variable, and (0.844) for tax revenues (second dependent variable). All these values are proper and adequate for the purposes of the study, showing high and proper persistence values.

\section{Results and Discussion}

\subsection{Independent Variable (Income Tax)}

The researcher used a 3-scale method to describe the arithmetic mean of the research sample individuals as follows:

Low: if the value of the arithmetic mean is less than (2.33), medium: if the value of the arithmetic mean is between $(2.33-3.67)$, and high: if the value of the arithmetic mean is between $(3.67-5.00)$.

Table 2 shows independent variable paragraphs (income tax).

Table 2

\begin{tabular}{|c|c|c|c|c|c|}
\hline NO & Paragraph & $\begin{array}{l}\text { Arithmetic } \\
\text { mean }\end{array}$ & $\begin{array}{l}\text { Std. } \\
\text { Deviation }\end{array}$ & Level & Rank \\
\hline 1 & $\begin{array}{l}\text { Management is interested in investment portfolio to } \\
\text { achieve returns and gains }\end{array}$ & 4.28 & 0.77 & high & 1 \\
\hline 9 & $\begin{array}{l}\text { Management is concerned of censorship the } \\
\text { revenues }\end{array}$ & 4.21 & 0.74 & high & 2 \\
\hline 7 & $\begin{array}{l}\text { The company is interested in achieving the highest } \\
\text { return }\end{array}$ & 4.19 & 0.63 & high & 3 \\
\hline 10 & Management monitors liquidity risk for returns & 4.15 & 0.72 & high & 4 \\
\hline 6 & $\begin{array}{l}\text { The company works to open internal and external } \\
\text { markets to achieve returns }\end{array}$ & 4.14 & 0.80 & high & 5 \\
\hline 5 & Dividends are distributed to the shareholders & 4.13 & 0.85 & high & 5 \\
\hline 3 & Management discloses the real profits and returns & 4.05 & 0.80 & high & 6 \\
\hline 8 & $\begin{array}{l}\text { There is a correlation between revenues and } \\
\text { expenses }\end{array}$ & 4.05 & 0.68 & high & 7 \\
\hline 4 & Company follows investment policies & 4.03 & 0.78 & high & 8 \\
\hline \multirow[t]{2}{*}{2} & $\begin{array}{l}\text { Management is concerned with the existence of an } \\
\text { audit committee to maintain the level of credibility } \\
\text { of the data that is disclosed about the profitability } \\
\text { and revenues achieved by parties related to the } \\
\text { company }\end{array}$ & 4.02 & 0.80 & high & 10 \\
\hline & Income Tax & 4.13 & 0.54 & high & \\
\hline
\end{tabular}


Table 2 shows that the income tax domain level was high, reaching an arithmetic mean value of (4.13), the paragraphs domain level was also high ranging between $(4.28$ - 4.02). Paragraph (1) ranked first, stating "the tax performance contributes to tax and social justice to all taxpayers", with an arithmetic mean of (4.28), while Paragraph (2) stating "tax performance gives importance to opening foreign and domestic channels" came last with an arithmetic mean of (4.29).

\subsection{Dependent Variable (Application of Accounting Billing Systems)}

Table 3 presents of the first dependent variable paragraphs (application of accounting billing systems.

Table 3

\begin{tabular}{llcccc}
\hline NO & \multicolumn{1}{c}{ Paragraph } & $\begin{array}{c}\text { Arithmetic } \\
\text { mean }\end{array}$ & $\begin{array}{c}\text { Std. } \\
\text { Deviation }\end{array}$ & Level & Rank \\
\hline 12 & $\begin{array}{l}\text { Accounting billing is based on a tax legal } \\
\text { and legislative ground. }\end{array}$ & 4.29 & 0.78 & high & 1 \\
\hline 16 & $\begin{array}{l}\text { Accounting billing contributes to the } \\
\text { commitment of taxpayers }\end{array}$ & 4.29 & 0.73 & high & 2 \\
\hline 15 & Accounting billing increases tax collection & 4.27 & 0.81 & high & 3 \\
\hline 14 & $\begin{array}{l}\text { Accounting billing is a financial basis for } \\
\text { taxes. }\end{array}$ & 4.21 & 0.82 & high & 4 \\
\hline 13 & $\begin{array}{l}\text { Tax payers commit themselves to paying } \\
\text { taxes with the application of the } \\
\text { accounting billing. }\end{array}$ & 4.19 & 0.70 & high & 5 \\
\hline 17 & $\begin{array}{l}\text { Accounting billing increases the tax } \\
\text { administration's confidence in the } \\
\text { financial and accounting statements } \\
\text { submitted by taxpayers }\end{array}$ & 4.18 & 0.69 & high & 5 \\
\hline 11 & $\begin{array}{l}\text { Accounting billing contributes to } \\
\text { combating tax evasion. }\end{array}$ & 4.16 & 0.86 & high & 6 \\
\hline 18 & $\begin{array}{l}\text { Accounting billing ensures the integrity of } \\
\text { the financial and accounting statements } \\
\text { against manipulation by taxpayers. }\end{array}$ & 4.12 & 0.76 & high & 7 \\
\hline $\begin{array}{l}\text { Accounting billing contributes to a true } \\
\text { value of the taxpayer financial and } \\
\text { accounting information. }\end{array}$ & $\begin{array}{l}\text { Accounting billing contributes to } \\
\text { taxpayers turnout in providing accounting } \\
\text { programmes. }\end{array}$ & 3.11 & 0.77 & high & 8 \\
\hline \begin{tabular}{l} 
Application of accounting Billing Systems \\
\hline
\end{tabular} & $\mathbf{4 . 1 8}$ & $\mathbf{0 . 5 3}$ & high & \\
\hline
\end{tabular}

Table 3 shows that the application of the accounting billing systems domain level was high, amounting to an arithmetic mean value of (4.18), the level of the paragraphs domain was high, the arithmetic means ranging between (4.29 - 3.94). Paragraphs (12) and (16) came first. Paragraph (12) states that "accounting billing is based on legal and legislative tax", whereas Paragraph (16) states that "accounting billing contributes to taxpayers commitment" respectively, with an average mean amounting to (4.29), while Paragraph (19) which states "accounting billing contributes to taxpayers turnout in providing accounting programmes", with an arithmetic value of (3.94).

5.3 Dependent Variable (Tax Revenues)

Table 4 shows independent variable paragraphs (tax revenues) 
Table 4

\begin{tabular}{|c|c|c|c|c|c|}
\hline NO & Paragraph & $\begin{array}{l}\text { Arithmetic } \\
\text { mean }\end{array}$ & $\begin{array}{c}\text { Std. } \\
\text { Deviation }\end{array}$ & Level & Rank \\
\hline 26 & $\begin{array}{l}\text { The adoption of a law of penalty for delay in } \\
\text { submission of tax return increases tax revenue. }\end{array}$ & 4.28 & 0.79 & high & 1 \\
\hline 23 & $\begin{array}{l}\text { Tough law on tax evaders increases tax } \\
\text { revenues. }\end{array}$ & 4.12 & 0.73 & high & 2 \\
\hline 22 & Higher tax ratios increase tax revenues. & 4.09 & 0.76 & high & 3 \\
\hline 25 & $\begin{array}{l}\text { Accounting billing contributes to equity and } \\
\text { fairness in the tax collection process. }\end{array}$ & 4.06 & 0.79 & high & 4 \\
\hline 21 & Tax diversification increases tax revenues & 4.05 & 0.79 & high & 5 \\
\hline 24 & $\begin{array}{l}\text { Encouraging investment and starting new } \\
\text { projects increases tax revenue }\end{array}$ & 4.02 & 0.78 & high & 5 \\
\hline 30 & $\begin{array}{l}\text { Fair and objective tax reforms increase tax } \\
\text { collection }\end{array}$ & 3.98 & 0.75 & high & 6 \\
\hline 28 & $\begin{array}{l}\text { The stability of taxpayer tax laws increases tax } \\
\text { revenues. }\end{array}$ & 3.94 & 0.83 & high & 7 \\
\hline 29 & $\begin{array}{l}\text { Maintaining a domestic and foreign investor } \\
\text { within the state increases tax revenue. }\end{array}$ & 3.94 & 0.71 & high & 8 \\
\hline \multirow[t]{2}{*}{27} & $\begin{array}{l}\text { The flexibility of the tax system increases tax } \\
\text { revenues }\end{array}$ & 3.77 & 0.96 & high & 10 \\
\hline & Tax revenues & 4.03 & 0.51 & high & \\
\hline
\end{tabular}

Table 4 shows that the level of the tax revenues domain was high, amounting to an arithmetic mean value of (4.03), the level of the paragraphs domain was high, the arithmetic means ranging between (3.77- 4.28). Paragraph (26) came first, stating that "the adoption of the law of penalties for delay in submission of the tax return increases tax revenues", with an arithmetic mean amounted to (4.28), while paragraph (27) "the flexibility of the tax system increases tax revenues ", ranked last with an arithmetic mean amounted to (3.77).

\subsection{Testing Study Hypotheses}

$\mathbf{H}_{\mathbf{0 1}}$ : There is no statistically significant impact of income tax on the application of accounting billing systems in Jordan.

Table 5 presents the results of the simple linear regression analysis regarding the income tax performance impact on the application of the accounting billing systems as follows.

Table 5

\begin{tabular}{ccccccccc}
\hline $\begin{array}{c}\text { Independent } \\
\text { variable }\end{array}$ & $\mathbf{r}$ & $\mathbf{R}^{2}$ & $\mathbf{f}$ & $\boldsymbol{S i g} \mathbf{f}$ & $\boldsymbol{\beta}_{\mathbf{0}}$ & $\boldsymbol{\beta}$ & $\mathbf{t}$ & Sig t \\
\hline Income Tax & 0.653 & 0.426 & 104.11 & $* 0.000$ & 1.547 & 0.638 & 10.20 & $* 0.000$ \\
\hline
\end{tabular}

$\mathbf{H}_{\mathbf{0 2}}$ : There is no statistically significant impact of the income tax on tax revenues in Jordan.

Table 6 shows the results of this simple linear regression analysis on the impact of the performance of income tax on tax revenues as follows:

Table 6

\begin{tabular}{ccccccccc}
\hline $\begin{array}{c}\text { Independent } \\
\text { variable }\end{array}$ & $\mathbf{r}$ & $\mathbf{R}^{2}$ & $\mathbf{f}$ & $\operatorname{Sig} \mathbf{f}$ & $\boldsymbol{\beta}_{\mathbf{0}}$ & $\boldsymbol{\beta}$ & $\mathbf{t}$ & Sig t \\
\hline Income Tax & 0.650 & 0.423 & 102.50 & $* 0.000$ & 1.504 & 0.611 & 10.12 & $* 0.000$ \\
\hline
\end{tabular}




\section{Conclusions}

The results of the study are limited to data analysis and testing of study hypotheses as follows:

1- There is an impact of statistical significance (the first hypothesis) of the impact of income tax on the application of the accounting billing systems in Jordan, where the value of the correlation between the two variables amounted to (0.653), and considered statistically significant, since the value of (f) calculated and amounted to (104.11) is statistically significant at the level of significance $(0.000)$, being less than $(5 \%)$. This result indicates the impact of income tax on the application of the accounting billing systems in Jordan.

2- The value of the coefficient $(\beta)$ indicates the impact of income tax on the application of the accounting billing systems in Jordan in the regression model reached, where the value of this effect is (0.638).

3- The value (t) also indicates the significance of the linear coefficient $(\beta)$ that has been reached, and since the value of the significance level $(0.000)$ for the accounting billing systems variable was less than $(5 \%)$, the value of coefficients that have been reached are of importance in the regression model.

4- The value of (R2) shows the contrast ratio of the dependent variable. It reached a percentage of $(42.6 \%)$.

5- With such results, the null study hypothesis is rejected and the alternative accepted, i.e. there is an effect of income tax on the application of accounting invoicing systems in Jordan.

6- There is an impact of statistical significance (the second hypothesis) of the impact of the income tax on tax revenues in Jordan, where the value of the correlation between the two variables amounted to (0.650), and considered statistically significant, since the value of (f) calculated and amounted to (102.50) is statistically significant at the level of significance (0.000), being less than (5\%). This result indicates the impact of income tax on tax revenues in Jordan.

7- The value of the coefficient $(\beta)$ indicates the impact of income tax on tax revenues in Jordan in the regression model reached, this effect is $(0.611)$.

8- The value ( $\mathrm{t}$ ) also indicates the significance of the linear coefficient $(\beta)$, the value of the significance level $(0.000)$ for the tax revenues variable was less than $(5 \%)$.

9- The value of (R2) shows the contrast ratio of the dependent variable. It reached a percentage of $(42.6 \%)$.

10- This result rejects the null study hypothesis and accepts the alternative i.e. there is an impact of income tax on tax revenues in Jordan.

11-The study studies the use of accounting invoicing in the future to collect tax from high-income groups, to reduce the tax gap between financial incomes.

\section{Recommendations}

The researcher has recommended the following:

1- There are positive correlations for the state treasury using the tax billing system.

2- The tax billing system must be applied to all sectors to combat tax evasion.

3- The principle of tax justice for all shall be applied.

\section{References}

Abu Nassar, M. (2019). Tax Accounting (3rd ed.). Wael Publishing and Distribution, Amman - Jordan.

Al Karaawy, A. (2018). The Impact of International Taxation Systems Variations on the Application of Financial Accounting Principles. Jordan. Retrieved https://www.abacademies.org/articles/the-impact-of-international-taxation-systems-variations-on-the-applicatio n-of-financial-accounting-principles-7145.html

Al-Qarala, N., \& Al Baaj, Q. M. (2018). Billing of the Income Tax Law. University of Al Qadisiyah, 22(2). Retrieved from http://alrai.com/article/10442554/

Bensaghir, F. (2019). For Whom the Electronic Billing Tolls. Morocco. Retrieved from https://www.hespress.com/writers/418770.html

Broadberry, S., \& Leuning, T. (2013). The Impact of Government Policies on UK Manufacturing Since 1945. London School of Economics, Government Office for Science, UK. Retrieved from https://assets.publishing.service.gov.uk/government/uploads/system/uploads/attachment_data/file/277158/ep2-g 
overnment-policy-since-1945.pdf

JESC, Jordan Economic and Social Council. (2014). Tax Evasion in Jordan (Causes, Methods, and Size). Amman Jordan. Retrieved from http://www.ammanchamber.org.jo/Uplaoded/PRFiles/trw.pdf

Mameche, Y. (2018). An analytical study of the accounting practices for income tax in the light of the Algerian accounting system based on IAS/IFRS: The case of the Algerian companies. Jordan Journal of Business Administration, 14(2).

Nicu Popa, A. F. (2015). The Impact of Accounting and Fiscal Regulations on Corporate Income Tax Information Provided to Stakeholders. University of Economic, Ucharest University of Economic Studies, Bucharest, Romania. Retrieved from https://www.researchgate.net/publication/318702820_The_impact_of_accounting_and_fiscal_regulations_on_c orporate_income_tax_information_provided_to_stakeholders

Rahhal, H. (2011). The Impact of the Temporary Income Tax Law No, 28, 2009 on Encouraging Investment in Jordan. Department of Accounting, Commerce College, Middle East University, Amman - Jordan. Retrieved from https://meu.edu.jo/libraryTheses/586b7845729ca_1.pdf

Yousfi, N. (2016). Impact of tax policy on investment. Faculty of Law and Political Science, University of Mohamed Khidr (Biskra) - Algeria. Retrieved from http://revues.univ-biskra.dz/index.php/dlsc/article/view/3210/2879

\section{Copyrights}

Copyright for this article is retained by the author(s), with first publication rights granted to the journal.

This is an open-access article distributed under the terms and conditions of the Creative Commons Attribution license (http://creativecommons.org/licenses/by/4.0/). 